\title{
Leafhoppers of the genus Macropsis Lewis, 1836 (Homoptera: Auchenorrhyncha: Cicadellidae: Macropsinae) on Sakhalin - different evolutionary trends in different species
}

\author{
Цикадки рода Macropsis Lewis, 1836 \\ (Homoptera: Auchenorrhyncha: Cicadellidae: Macropsinae) \\ на Сахалине: разные эволюџионные тенденџии у разных видов
}

\author{
D.Yu. Tishechkin \\ А.Ю. Тишечкин
}

Department of Entomology, Faculty of Biology, M.V. Lomonosov Moscow State University, Vorobyevy Gory, Moscow, 119234 Russia. Email: macropsis@yandex.ru

Кафедра энтомологии Биологического факультета Московского государственного университета имени М.В. Ломоносова, Воробьевы Горы, Москва, 119234 Россия.

KEY WORDS: Homoptera, Auchenorrhyncha, Cicadellidae, Macropsis, Sakhalin, insular populations, speciation, evolution.

КЛЮЧЕВЫЕ СЛОВА: Homoptera, Auchenorrhyncha, Cicadellidae, Macropsis, Сахалин, островные популяции, видообразование, эволюция.

ABSTRACT. Illustrated descriptions of six species of the genus Macropsis from Sakhalin with data on host plants and male calling signals are given. For each species comparison with the mainland populations of the same or sister species is provided. Species studied demonstrate different evolutionary scenarios in insular populations. In M. fuscinervis, M. suspecta, and $M$. costalis no differences in any traits between the mainland and insular populations were revealed. In M. hinganensis the range of colour variability on Sakhalin is much wider than in the mainland. M. fuscula has two colour variations, the dark form occurs in the Western Palaearctic, and the light form in the Far East; Far Eastern specimens from the mainland and insular populations are indistinguishable in coloration. M. remota is undoubtedly an insular sister form of a widespread East Palaearctic M. flavida, but these forms distinctly differ in morphological traits and apparently, already reached the rank of good species. Thus, only in one of six forms insular isolation resulted in speciation. In all insular forms including $M$. remota calling signal patterns remained unchanged compared to the mainland populations. This proves that in geographically isolated forms, morphological divergence can occur without divergence of calling signal patterns. The number of species of Macropsis on Sakhalin is considerably less, than in the adjacent part of the mainland. Apparently, the cold climate is the main reason for the absence of some mainland species on Sakhalin; the impact of geographic isolation in this case is not so great.

РЕЗЮМЕ. Приведены иллюстрированные описания и сведения о кормовых растениях и призывных сигналах самцов шести видов Macropsis с Cахалина в сравнении с теми же или сестринскими видами с материка. У разных видов в островных популяциях наблюдаются разные эволюционные сценарии. У M. fuscinervis, M. suspecta и M. costalis никаких различий между материковыми и островными популяциями ни по одному из признаков не выявлено. У M. hinganensis диапазон цветовой изменчивости в сахалинской популяции гораздо шире, чем на материке. У M. fuscula имеются две цветовые вариации: тёмная форма обитает в Западной Палеарктике, светлая — на Дальнем Востоке; при этом особи из материковой части Дальнего Востока и с Сахалина и Курильских островов по окраске не различаются. M. remota, несомненно, представляет собой островную сестринскую форму широко распространённого материкового M. flavida, но значительно отличается от него по морфологическим признакам и, по-видимому, уже достиг видового статуса. Таким образом, только у одной из шести форм островная изоляция привела к видообразованию. У всех островных форм, включая M. remota, временной паттерн призывного сигнала остаётся таким же, как

How to cite this article: Tishechkin D.Yu. 2019. Leafhoppers of the genus Macropsis Lewis, 1836 (Homoptera: Auchenorrhyncha: Cicadellidae: Macropsinae) on Sakhalin - different evolutionary trends in different species // Russian Entomol. J. Vol.28. No.2. P.107-119. doi: 10.15298/rusentj.28.2.01 
в материковых популяциях. Это свидетельствует о том, что при географической изоляции морфологическая дивергенция может происходить без изменения структуры сигналов. Число видов Macropsis на Сахалине значительно меньше, чем на материке. Очевидно, это можно объяснить более холодным климатом; влияние географической изоляции в данном случае не столь велико.

\section{Introduction}

Macropsinae (Homoptera: Auchenorrhyncha: Cicadellidae) of Sakhalin are still insufficiently studied. Matsumura [1911] described Macropsis costalis (Matsumura, 1911) and recorded Oncopsis tristis (Zetterstedt, 1840) from the southern part of the island. Nast
[1972] listed from Sakhalin two more species, M. marginata (Herrich-Schäffer, 1836) and M. prasina (Boheman, 1852), but both records are erroneous [Tishechkin, 1999]. In the comprehensive work of Anufriev \& Emelyanov [1988] only O. tristis and O. flavicollis (Linnaeus, 1761) were recorded from Sakhalin; the record of the latter species should be attributed to $O$. burjatica Tishetshkin, 2008 [Okudera, 2014; Tishechkin, 2017]. About 20 years ago we described M. remota Tishetshkin, 1998 from South Sakhalin based on several dry specimens [Tishechkin, 1998]; host plant and male calling signal of this species so far remained unknown. In the recent review of the genus Oncopsis of Russia and adjacent countries we recorded from Sakhalin O. tristis, O. burjatica, O. nitobei (Matsumura, 1912), O. sepulcralis Anufriev, 1967, O. caliginosa

Data for signal recordings presented on oscillograms. Данные о записях сигналов, представленных на осциллограммах.

\begin{tabular}{|c|c|}
\hline ecies & $\mathrm{g}$ \\
\hline $\begin{array}{l}\text { is } \\
\text { is }\end{array}$ & $\begin{array}{l}\text { South Sakhalin, environs of Sokol Town, Populus tremula, 24.VII.2015, signals of } 38 \delta \\
\text { orded on disk at } 23 \text { and } 25^{\circ} \mathrm{C} \text {. } \\
\text { Primorsky Krai, Pogranichny District, environs of Barabash-Levada Village, P. tremula, } \\
\text { VII.1995, signals of } 2 \delta^{\star}{ }^{\circ} \text { recorded on tape at } 23-24^{\circ} \mathrm{C} \text {. }\end{array}$ \\
\hline $\begin{array}{l}\text { M. s } \\
\text { Tish }\end{array}$ & 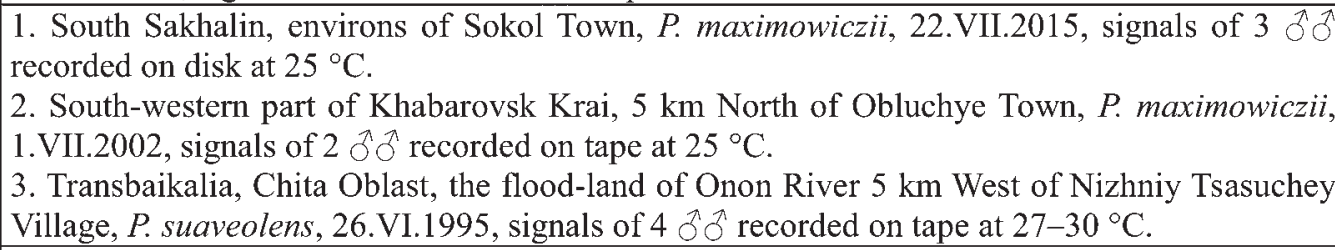 \\
\hline $\begin{array}{l}\text { M. cos } \\
\text { (Mats. }\end{array}$ & $\begin{array}{l}\text { 1. South Sakhalin, environs of Sokol Town, Salix schwerinii, 23.VII.2015, signals of } 3 \delta \delta \\
\text { recorded on disk at } 25^{\circ} \mathrm{C} \text {; same locality and host, } 30 . \text { VII.2015, signals of } 1{ }^{\lambda} \text { recorded on disk } \\
\text { at } 27^{\circ} \mathrm{C} \text {. } \\
\text { 2. Primorsky Krai, ca. } 15 \mathrm{~km} \text { Southwest of Slavyanka, environs of Ryazanovka Village, S. } \\
\text { schwerinii, 18.VII.2012, signals of } 2 \partial^{\lambda} \partial \text { recorded on disk at } 23^{\circ} \mathrm{C} \text {. } \\
\text { 3. South-western part of Khabarovsk Krai, environs of Obluchye Town, S. schwerinii, } \\
\text { 5.VII.2012, signals of } 2 \partial \partial^{\lambda} \text { recorded on disk at } 24^{\circ} \mathrm{C} \text {. }\end{array}$ \\
\hline $\begin{array}{l}\text { M. ren } \\
\text { Tish. }\end{array}$ & 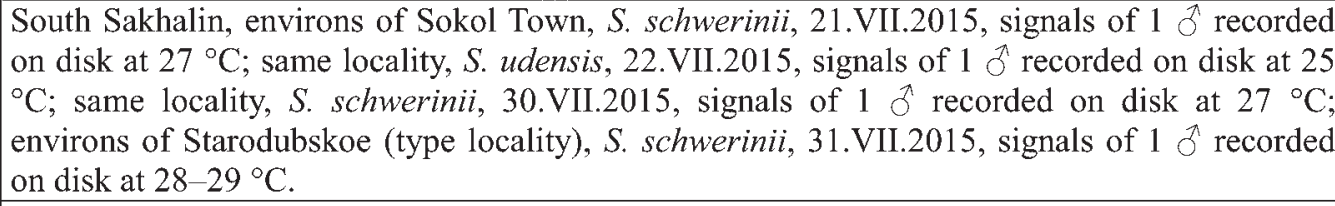 \\
\hline $\begin{array}{l}\text { M. fla } \\
\text { Vilb. }\end{array}$ & $\begin{array}{l}\text { Ivirons of Ryazanovka Village, } S \text {. } \\
20^{\circ} \mathrm{C} \text {. } \\
\text { irons of Kostyukovka Village, } S \text {. }\end{array}$ \\
\hline $\begin{array}{l}\text { M. hin } \\
\text { Tish. }\end{array}$ & 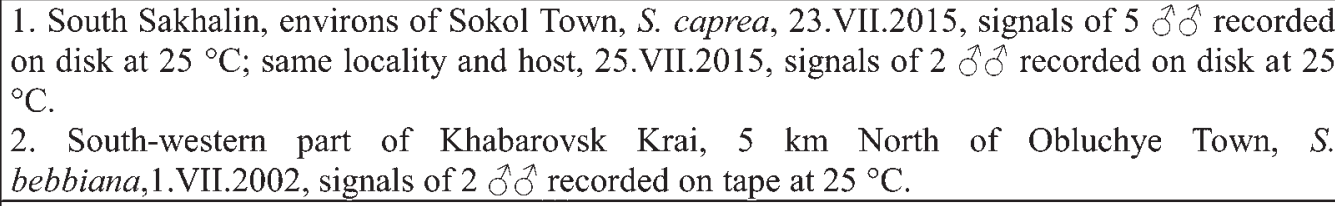 \\
\hline $\begin{array}{l}\text { M. fusc } \\
\text { (Zett.) }\end{array}$ & $\begin{array}{l}\text { 1. South Sakhalin, forest ca. } 6 \mathrm{~km} \text { West of Sokol Town, Rubus sachalinensis, 3.VIII.2015, } \\
\text { signals of } 1 \delta \text { recorded on disk at } 25-26^{\circ} \mathrm{C} \text {. } \\
\text { 2. Southern Kazakhstan, Almaty and Zailiyskiy Alatau Mtn. Range in the environs of the city, } \\
\text { R. caesius, 3.VII.1994, signals of } 4 \hat{\partial} \text { recorded on tape at } 30-31^{\circ} \mathrm{C} \text {. } \\
\text { 3. Moscow Oblast, Voskresensk District, environs of Beloozerskiy Town, R. caesius, } \\
\text { 13.VII.2000, signals of } 2 \hat{\partial} \text { recorded on tape at } 26^{\circ} \mathrm{C} \text {. }\end{array}$ \\
\hline
\end{tabular}


Anufriev, 1967, and O.planiscuta (Thomson, 1870); all records are based on the materials from the collections of Zoological Museum of M.V. Lomonosov Moscow State University and Zoological Institute of Russian Academy of Sciences, St. Petersburg [Tishechkin, 2017]. As a result, presently, six species of Oncopsis and two species of Macropsis are known from Sakhalin, not counting erroneous records.

During the fieldwork on South Sakhalin we collected six species of the genus Macropsis, investigated their host preferences, and made recordings of male calling signals. The aim of this paper is to provide comprehensive descriptions of these species in comparison with the same or sister species from the mainland. Calling signals of $M$. costalis and $M$. remota were not described in literature; their investigation in type localities allowed more reliable identification of these species. Comparison of the Sakhalin and mainland forms is of interest for studying the speciation processes in insular populations.

\section{Material and methods}

Investigations were carried out in the southern part of Sakhalin in the environs of Starodubskoe, Sokol, and between Prigorodnoe and Ozerskoe during the period from mid July to mid August 2015. All potential host plants occurring on Sakhalin were investigated; only several willow species known from one or two localities [Nedoluzhko, 1995] were not examined. Thus, despite the fact that we investigated only the southern part of the island, it can be assumed that the list of found species of Macropsis is quite complete.

Male vibrational calling signals were recorded by means of portable recording equipment consisting of a piezocrystal gramophone cartridge GZP-311 connected to the microphone input of a cassette recorder Elektronika-302-1 (before 2005) or minidisk recorder Sony Walkman MZ-NH900 via a custom-made matching amplifier. For recording, a twig of the host plant about $10-15 \mathrm{~cm}$ in length was attached to the cartridge by a rubber ring so that the cartridge needle touched the stem slightly. Then a nylon cage containing a male leafhopper was put on the twig. After a time, the male usually sat on the twig and started singing.

Data on signal recordings presented on oscillograms are given in the Table. Signal analysis was performed with Cool Edit Pro 2.1 software.

For elements of signal temporal pattern the following terms are used. Pulse is a brief elementary fragment of signal (or succession of sine waves) with rapid increase and subsequent decrease of amplitude, i.e. separated from similar fragments by amplitude minimums. Short fragments with constant temporal pattern usually repeated with regular intervals and consisting of uniform or different pulses are referred to as syllables. Any more or less prolonged signal with complex pattern (e.g. succession of similar or different syllables) is referred to as a phrase.
The drawings of penis and $2^{\text {nd }}$ abdominal apodemes of males from Sakhalin were made by tracing the outlines of digital photographs on a glass table lighted from underneath. Drawings of apodemes and penis of males from the mainland were taken from Tishechkin [1999, 2004]. Since in all studied species styles and pygofer processes do not bear species-specific traits, their drawings are not given.

All materials studied are deposited in the collection of the Zoological Museum of M.V. Lomonosov Moscow State University.

\section{Descriptions of species}

\section{Macropsis fuscinervis (Boheman, 1845)}

Figs 1-6, 54-65, 128-131.

COLORATION. The material on this species from Sakhalin is small, and it does not allow adequately assess the colour variability. All studied specimens have pale yellowish coloration with dark pattern (Figs 1-2) and belong to most common colour variation prevailing in all mainland populations (Figs 3-4). Light grey or yellowish females sometimes found in the mainland (Figs 5-6), were not found on Sakhalin.

MALE ABDOMINAL APODEMES AND PENIS. Abdominal apodemes of $2^{\text {nd }}$ tergite in male narrow, usually slightly bent inwards, separated by broad rounded notch (Figs 54-55). Sternal apodemes more or less triangular, strongly convergent, sometimes with expanded tips (Figs 5657). Penis rather broad in side view (Figs 58-59). We failed to find significant differences in the shape of apodemes and penis between the mainland (Figs 54-59) and insular (Figs 60-65) populations.

HOST PLANTS. Populus tremula L. across all the range from the Far East to Western Europe.

MALE CALLING SIGNAL. In all poplar-feeding Macropsis species no clear-cut distinction exists between calling and courtship signals. Normally, single male produces simple signal (calling signal in the strict sense). Sometimes it spontaneously produces a more complex signal, the same as when courting a female.

In males from Sakhalin only short signals were recorded. Signal of this type is a single phrase usually lasting from 5-7 up to $15-20 \mathrm{~s}$ (Figs 128-129). It begins with a succession of rather long pulses of the same amplitude following each other with a period of about 200-600 ms. Then follows a long succession of shorter pulses. It begins quietly and reaches maximum intensity at about one-third of its duration; pulse repetition period in it increases from $40-50$ up to $100-200 \mathrm{~ms}$. Signal temporal patterns in males from Sakhalin (Figs 128-129) and the mainland (Figs 130-131) are almost identical.

RANGE. Transpalaearctic.

REMARKS. No significant differences in any trait between the mainland and insular populations were found.

\section{Macropsis suspecta Tishetshkin, 1994} Figs 7-21, 66-78, 132-141.

COLORATION. In this species, coloration is extremely variable (Figs 7-21). Many local populations have unique combinations of colour variations and some rare variations are known from only one or two localities. The studied population from South Sakhalin (Figs 7-14) is characterized by a considerable proportion of variations with black pronotum (Figs 8, 11 , and 13 ), which are very rare in the mainland. However, the 


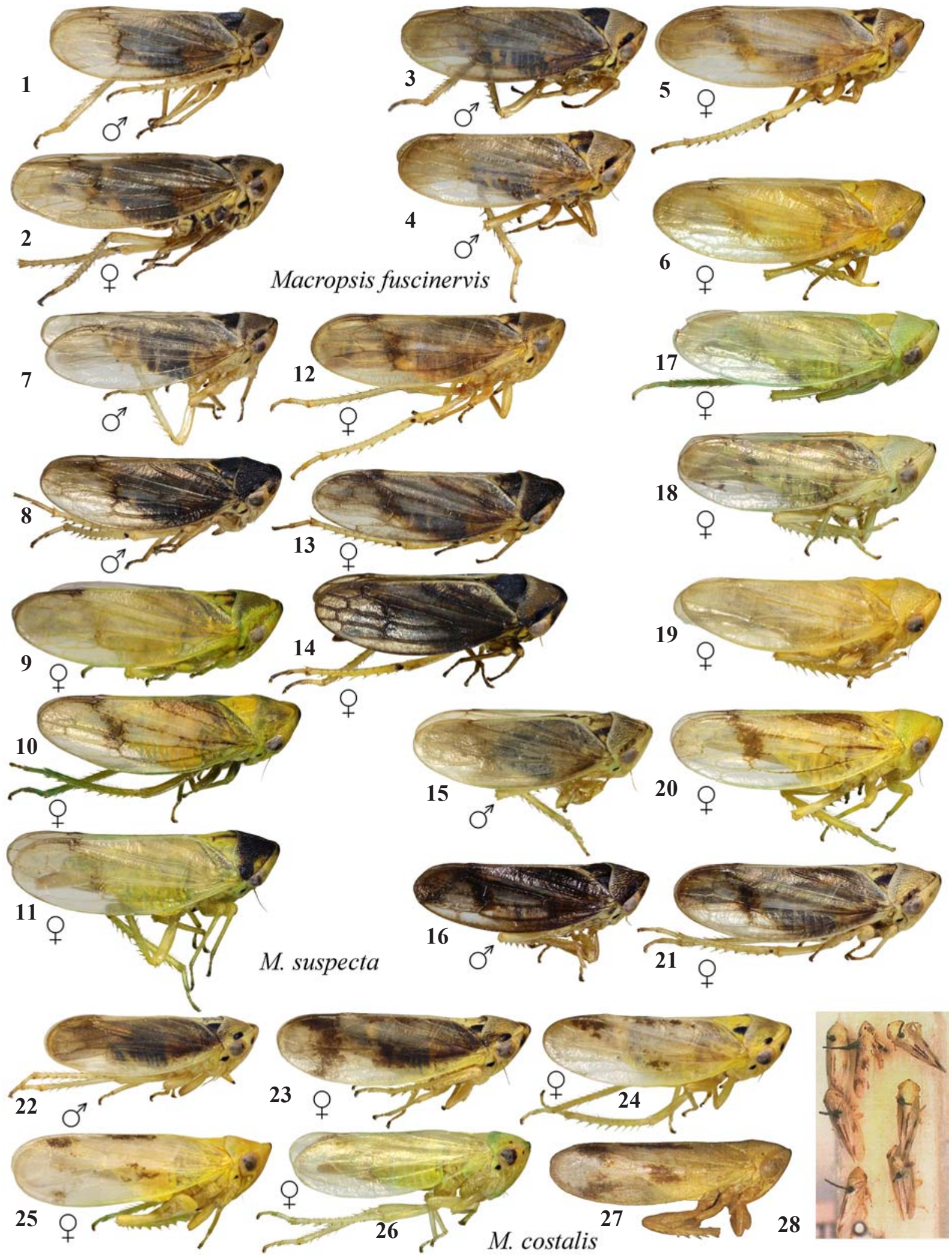

Figs 1-28. Macropsis spp: 1-6-M. fuscinervis; 7-21-M. suspecta; 22-28 - M. costalis; 1-2, 7-14, and 22-26 - specimens from Sakhalin; 3-6 and 15-21 - specimens from the mainland; 27-28 - type series of Pediopsis virescens var. stigmatipennis Matsumura, 1912, photos by Prof. M. Ohara.

Рис. 1-28. Macropsis spp: 1-6-M. fuscinervis; 7-21-M. suspecta; 22-28 - M. costalis; 1-2, 7-14 и 22-26 - экземпляры с Сахалина; 3-6 и 15-21 - экземпляры с материка; 27-28 - типовая серия Pediopsis virescens var. stigmatipennis Matsumura, 1912, фотографии проф. Охара. 

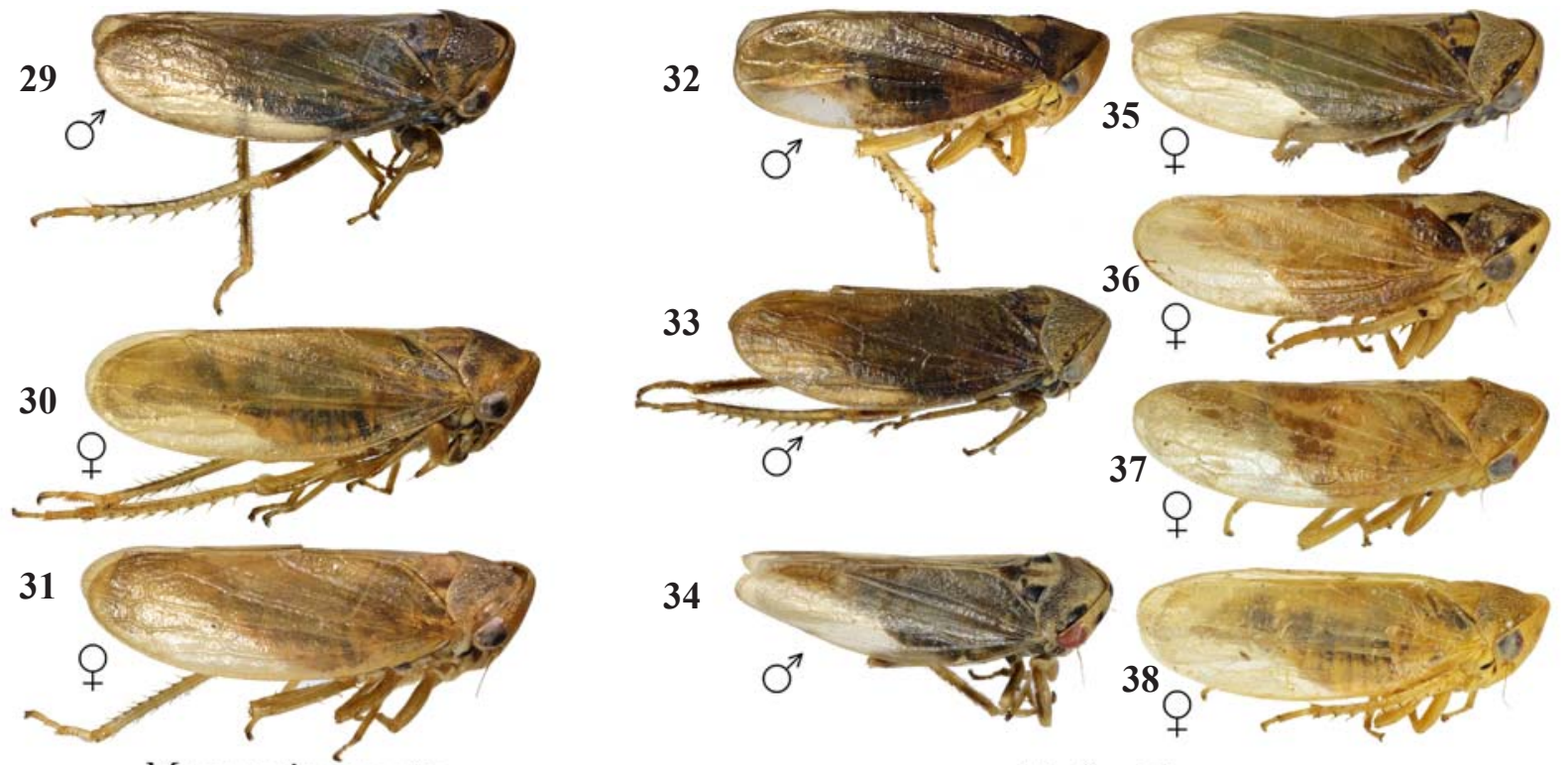

34
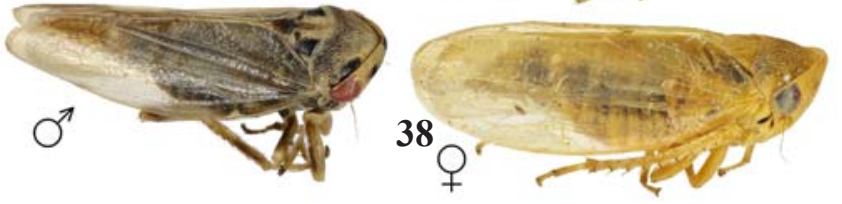

Macropsis remota

\section{M. flavida}

39
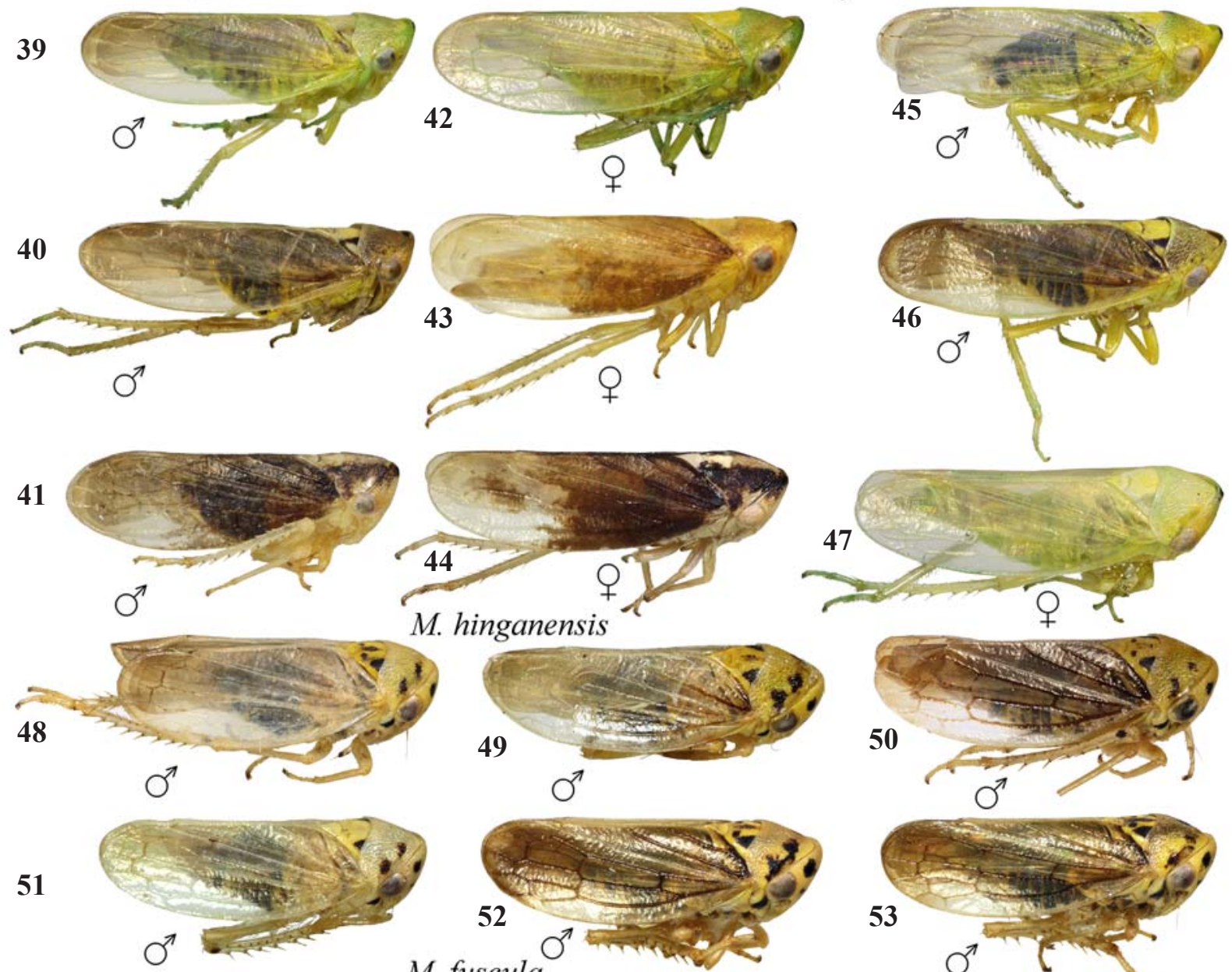

\section{M. fuscula}
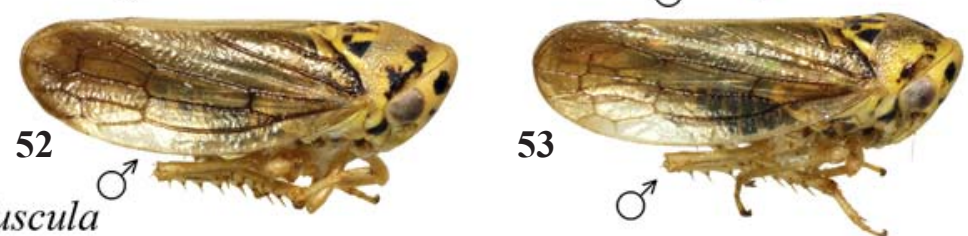

Figs 29-53. Macropsis spp: 29-31 - M. remota; 32-38 - M. flavida; 39-47-M. hinganensis (39-44 - specimens from Sakhalin, 45-47 — specimens from the mainland); 48-53 - M. fuscula (48 — specimen from Sakhalin, 49-50 — specimens from Kunashir, 51 specimen from Khabarovsk Krai, 52 - specimen from Southern Kazakhstan, 53 - specimen from Moscow Oblast).

Рис. 29-53. Macropsis spp: 29-31 - M. remota; 32-38 - M. flavida; 39-47-M. hinganensis (39-44 - экземпляры с Сахалина, 45-47 - экземпляры с материка); 48-53 - M. fuscula (48 - экземпляр с Сахалина, 49-50 — экземпляры с Кунашира, 51 экземпляр из Хабаровского края, 52 - экземпляр из Южного Казахстана, 53 - экземпляр из Московской обл.). 
presence of these variations in the sample from the environs of Sokol Town on Sakhalin is not a proof of differences between the mainland and insular populations in general.

MALE ABDOMINAL APODEMES AND PENIS. In the shape of male $2^{\text {nd }}$ abdominal apodemes and penis is similar to the previous species (Figs 66-78).

HOST PLANTS. Populus laurifolia Lebeb. and P. suaveolens Fischer in Siberia; P. maximowiczii A. Henry in the Russian Far East including Sakhalin.

MALE CALLING SIGNAL. In males from Sakhalin short (Figs 132-133) and complex (Figs 136-138) forms of calling signal were recorded. Short form of the signal in M. suspecta is similar to that in M. fuscinervis (Figs 128-131 and 132-135). Complex signal is a phrase consisting of several different parts (Figs. 136-141); it differs from the complex signal of $M$. fuscinervis by the presence of additional components at the beginning of a phrase [for details see Tishechkin, 1999]. Temporal patterns of signals of both types in males from Sakhalin (Figs 132-133 and 136-138) and the mainland (Figs 134-135 and 139-141) are identical.

RANGE. South-eastern Kazakhstan, Siberia, Northern Mongolia, and the Russian Far East. Was introduced to Kyrgyzstan (northern shore of the Issyk-Kul' Lake) with cultivated P. laurifolia and Populus sp.

REMARKS. In morphological and acoustic traits, no significant differences between the mainland and insular populations were found.

\section{Macropsis costalis (Matsumura, 1911)}

$$
\text { Figs 22-28, 79-91, 142-147. }
$$

= Pediopsis virescens var. stigmatipennis Matsumura, 1912: 307

= Macropsis stigmatipennis (Matsumura, 1912) (synonymy by Tishechkin, 2002).

COLORATION. Male pale yellow or pale green with dark spots on head, pro- and mesonotum, forewings strongly darkened, with light costal margin (Fig. 22). In female, dark coloration reduced to more or less extent so, that a variation range from dark to almost uniformly pale green specimens can be observed (Figs 23-26). Almost all colour variations were found both in the mainland and in the Sakhalin populations; only most light coloured variation (Fig. 26) is absent in our material from the mainland, possibly, due to insufficient material.

MALE ABDOMINAL APODEMES AND PENIS. Abdominal apodemes of $2^{\text {nd }}$ tergite in male of a peculiar shape, bilobed (Figs 79-80). Sternal apodemes very broad at base, of equilateral triangular outlines (Figs 81-82). Penis in side view rather short and broad (Figs 83-84). Males from Sakhalin (Figs 79-84) and the mainland (Figs 85-91) do not differ in the shape of apodemes and penis.

HOST PLANTS. Salix schwerinii, occasionally, also $S$. udensis.

MALE CALLING SIGNAL. Calling signal consists of complex phrases following each other almost without gaps (Figs 142, 145). The phrase includes several components, each formed by pulses or short syllables (Figs 143-144, 146-147). Male can sing unceasingly for several minutes. Signal temporal patterns in males from Sakhalin (Figs 142144) and the mainland (Figs 145-147) are identical.

RANGE. Khabarovsk Krai, Southern part of Primorsky Krai, Sakhalin, Southern Kurile Islands, Japan.

REMARKS. In morphological and acoustic traits, no significant differences between the mainland and insular populations were found.

M. costalis was described from the Lake Tunaicha (Tonnaitcha) and Chipsani (presently, Ozerskoe), Sakhalin [Matsumura, 1911]. One year later it was described from Sapporo, Hokkaido, Japan under the name Pediopsis virescens var. stigmatipennis Matsumura, 1912 based on a series of specimens with moderately developed black pattern [Matsumura,

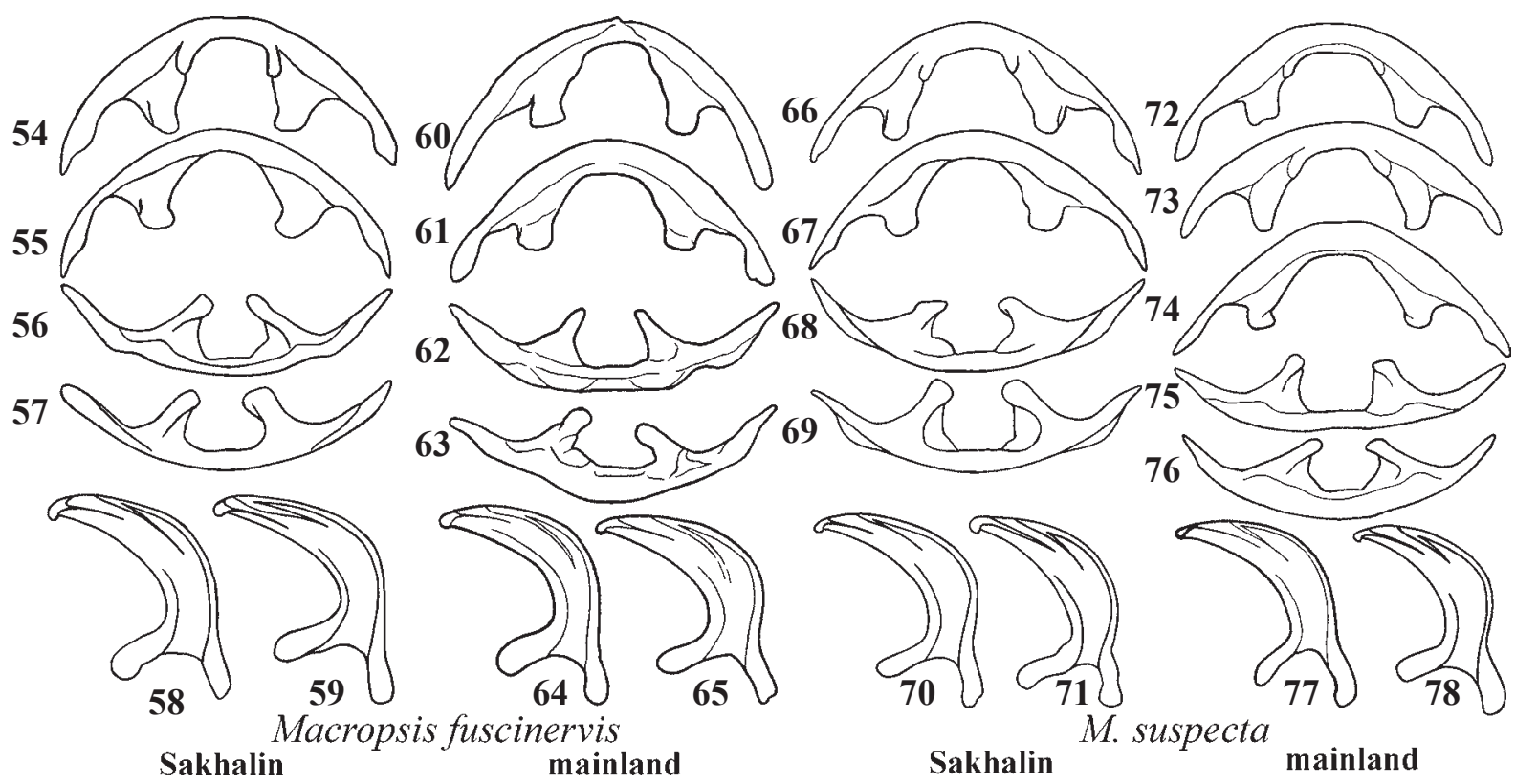

Figs 54-78. Macropsis spp.: 54-65 - M. fuscinervis; 66-78 - M. suspecta; 54-55, 60-61, 66-67, and 72-74 - male abdominal apodemes of the $2^{\text {nd }}$ tergite; $56-57,62-63,68-69$, and $75-76-$ the $2^{\text {nd }}$ sternite; $58-59,64-65,70-71$, and $77-78-$ penis, lateral view. $54-$ 59 and 66-71 - males from Sakhalin; 60-65 and 72-78 - males from the mainland.

Рис. 54-127. Macropsis spp.: 54-65 - M. fuscinervis; 66-78 - M. suspecta; 54-55, 60-61, 66-67 и 72-74- аподемы II брюшного тергита самца; 56-57, 62-63, 68-69 и 75-76 - аподемы II брюшного стернита; 58-59, 64-65, 70-71 и 77-78 - пенис сбоку; 54-59 и 66-71 - самцы с Сахалина, 60-65 и 72-78 - самцы с материка. 
1912]. We have studied photographs of a type series, which includes 7 specimens, apparently, females with the label "Sapporo, Matsumura" mounted together on the same pin [Figs 2728; Tishechkin, 2002]. As can be seen from these photographs, all specimens belong to the green variation of $M$. costalis.

In the original description the name is written as "stimatipennis"; in all later works it is written as "stigmatipennis". In accordance with Article 33.3.1 of the International Code of Zoological Nomenclature [2000], an incorrect subsequent spelling, which is in prevailing use and attributed to the publication containing the original spelling, should be considered the correct original spelling. For this reason, here we use the name "stigmatipennis". As noted in the preface to the Russian translation of the Code (comment 16), the abovementioned article allows ambiguous interpretation, but in this situation, even if uncertainty arises, the question is not of practical importance, since the changed name is a junior synonym.

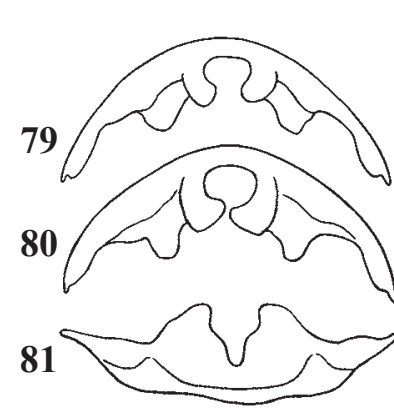

82<smiles></smiles>

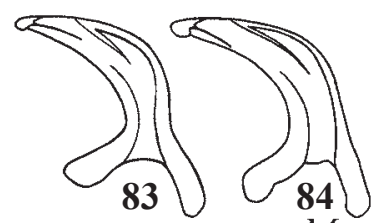
M. costalis

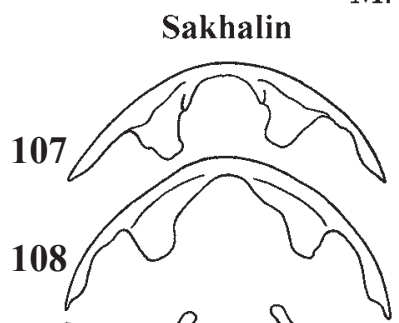

109<smiles>c1ccc(C23CC4CC(CC(C4)C2)C3)cc1</smiles>

110

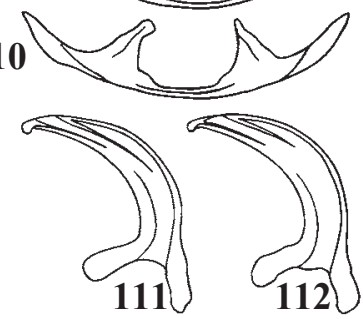

Sakhalin $M$. hinganensis mainland

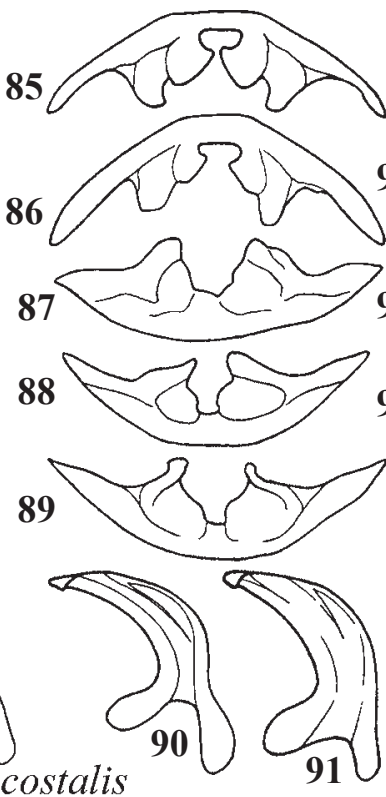

mainland
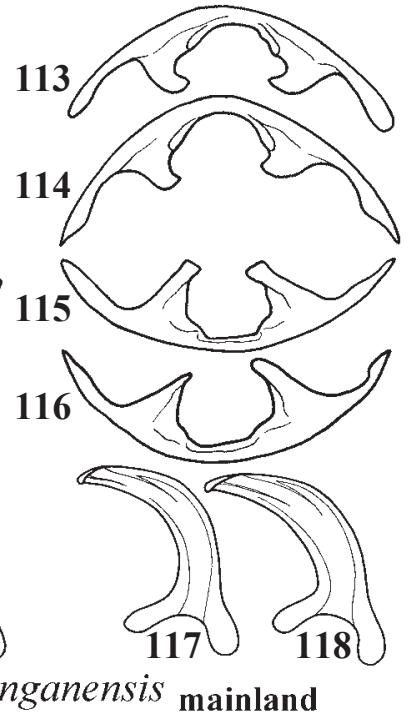

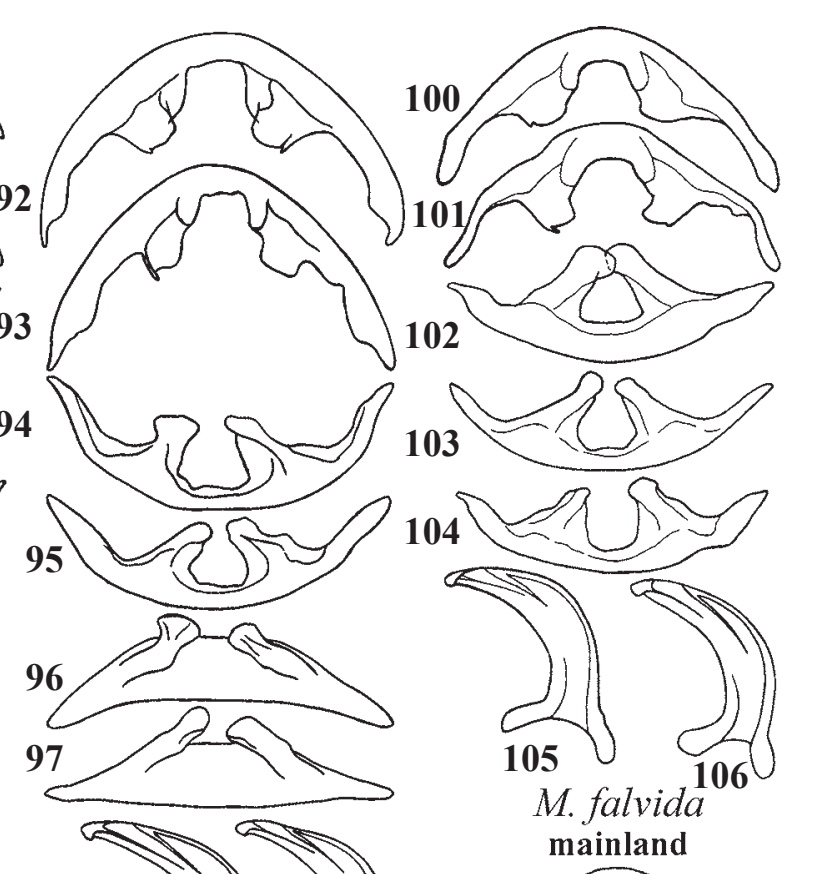

Figs 79-127. Macropsis spp.: 79-91 — M. costalis; 92-99 — M. remota; 100-106 - M. flavida; 107-118 - M. hinganensis; 119127 - M. fuscula; 79-80, 85-86, 92-93, 100-101, 107-108, 113-114, 119, and 122-123 - male abdominal apodemes of the $2^{\text {nd }}$ tergite; $81-82,87-89,94-97,102-104,109-110,115-116,120$, and $124-125$ - the $2^{\text {nd }}$ sternite; 83-84, 90-91, 98-99, 105-106, 111-112, 117118, 121, and 126-127 - penis, lateral view; 79-84, 92-99, 107-112, and 119-121 - males from Sakhalin; 85-91, 100-106, 113-118, and $122-127$ - males from the mainland.

Рис. 79-127. Macropsis spp.: 79-91 - M. costalis; 92-99 - M. remota; 100-106 - M. flavida; 107-118 - M. hinganensis; 119127 - M. fuscula; 79-80, 85-86, 92-93, 100-101, 107-108, 113-114, 119 и 122-123 - аподемы II брюшного тергита самца; 81-82, 87-89, 94-97, 102-104, 109-110, 115-116, 120 и 124-125 - аподемы II брюшного стернита; 83-84, 90-91, 98-99, 105-106, 111-112, 117-118, 121 и 126-127 - пенис сбоку; 79-84, 92-99, 107-112 и 119-121 — самцы с Сахалина; 85-91, 100-106, 113-118 и 122127 - самцы с материка. 


\section{Macropsis remota Tishetshkin, 1998}

Figs 29-31, 92-99, 148-149.

COLORATION. Brown or dark brown, usually with dark pattern on pro- and mesonotum (Figs 29-31).

MALE ABDOMINAL APODEMES AND PENIS. Abdominal apodemes of $2^{\text {nd }}$ tergite rounded or somewhat angular (Figs 92-93). Sternal apodemes strongly convergent, separated by narrow notch (Figs 94-95). Apodeme tips rounded, but situated almost horizontally and for this reason often look pointed in frontal view (Figs 96-97). Penis rather slender, with long and almost straight distal part (Figs 98-99).

HOST PLANTS. Salix schwerinii, occasionally, also S. udensis.

MALE CALLING SIGNAL. Calling signal is a single phrase lasting from 7-10 to ca. $20 \mathrm{~s}$ (Fig. 148). Its main part consists of syllables following each other with a period from about 0.5 to $2 \mathrm{~s}$ (Fig. 149, the first half of the oscillogram); quite often the syllable repetition period decreases towards the end of the signal. The phrase ends with a sequence of high-amplitude click-like pulses and 2-6 short syllables consisting of one high-amplitude and ca. 10-20 low-amplitude pulses each (Fig. 149, the second half of the oscillogram).

RANGE. Sakhalin. Records from the mainland [Tishechkin, 1998, 1999] are evidently erroneous.

REMARKS. Was described based on five specimens from South Sakhalin; with some doubt we included into the type series several specimens from the Southern part of Primorsky Krai [Tishechkin, 1998]. Investigation of a large material and also, of host preferences and male calling signals of specimens from South Sakhalin lead us to the conclusion, that identification of specimens from the mainland is doubtful. Therefore, at present, only populations from Sakhalin can be attributed to this species with certainty.

Differs from the mainland sister species, M. flavida Vilbaste, 1980, by the shape of sternal apodemes (Figs 94-97 and 102-104), more narrow and elongated penis (Figs 98-99 and $105-106)$, and body length $(4.6-5.0 \mathrm{~mm}$ in males and 5.0-5.6 $\mathrm{mm}$ in females versus $3.7-4.7 \mathrm{~mm}$ and $4.0-5.0 \mathrm{~mm}$, respectively, in M. flavida). Also, in M. remota coloration is much less variable than in M. flavida (Figs 29-31 and 32-38).

$M$. remota was found only on two willow species from the section Vimen ( $S$. schwerinii and S. udensis), whereas $M$. flavida was collected from many species from the sections Vimen (S. schwerinii and S. udensis), Vetrix (S. bebbiana Sarg. and S. abscondita Laksch.), Arbuscella (S. rhamnifolia Pall.), Daphnella (S. rorida Laksch.), Helix (S. ledebouriana Trautv. and S. miyabeana Seem.), and Glaucae (S. glauca L.). Thus, $M$. flavida and $M$. remota share common host plants, but in M. remota host specialization is much narrower than in M. flavida.

Interestingly, despite all morphological and ecological differences, calling signal patterns in these two species are identical (Figs 148-149 and 150-153).

\section{Macropsis hinganensis Tishetshkin, 2004 Figs 39-47, 107-118, 154-159.}

COLORATION. Males from Sakhalin usually green or brownish with strongly darkened forewings (Figs 39-40), occasionally, pale yellow with two brown longitudinal stripes on head, pro-, and mesonotum and with brown basal halves of the forewings (Fig. 41). Females green with transparent forewings (Fig. 42) or yellow with brown pattern (Figs 4344); dark pigmentation in yellow females varies much more widely than in males.
In the population from Khabarovsk Krai only green or brownish specimens were found (Figs 45-47).

MALE ABDOMINAL APODEMES AND PENIS. Abdominal apodemes of $2^{\text {nd }}$ tergite rather narrow, sometimes slightly bent inwards, separated by wide notch (Figs 107108). Sternal apodemes triangular, with narrow tips, broadly separated by more or less rectangular notch (Figs 109-110). Penis slender, with almost parallel margins in side view (Figs 111-112). Males from Sakhalin (Figs 107-112) and the mainland (Figs 113-118) are similar in the shape of apodemes and penis.

HOST PLANTS. Salix caprea L., occasionally, also $S$. taraikensis Kimura on Sakhalin; S. bebbiana Sarg. in Khabarovsk Krai (all belong to the section Vetrix).

MALE CALLING SIGNAL. Calling signal is a single phrase increasing in amplitude towards the end and lasting from 5-6 to 15-20 s (Fig. 154). It consists of syllables following each other with a period of ca. 1.5-2.5 s. The shape of syllables changes gradually from the beginning to the end of a phrase. The initial syllables include 1-2 or no gaps, whereas the end syllables are separated by 3-4 gaps each (Figs 155-156). Signals of males from Sakhalin (Figs 154156) and from the mainland (Figs 157-159) are similar.

RANGE. Very rare species in the mainland, until now was known only from the type locality, $5 \mathrm{~km}$ North from Obluchye Town towards Khingansk, South-western part of Khabarovsk Krai; was not found on Salix sect. Vetrix in other regions of the Russian Far East. Was fairly abundant on Sakhalin on its host plants on dry glades, roadsides, and in other open habitats.

REMARKS. Coloration of specimens from Sakhalin is much more variable than in the only known population from the mainland. In morphological and acoustic traits no significant differences between the mainland and insular populations were found.

\section{Macropsis fuscula (Zetterstedt, 1828)}

Figs 48-53, 119-127, 160-168.

COLORATION. Pale yellow with black spots on head, pro-, and mesonotum. In specimens from the Russian Far East forewings are usually transparent (Figs 48-49, 51), only very occasionally smoky with dark veins (Fig 50 ). In specimens from Southern Kazakhstan (Fig. 52) and European Russia (Fig. 53) black pattern on head, pro-, and mesonotum is much more developed, forewings are always smoky with dark veins

MALE ABDOMINAL APODEMES AND PENIS. Abdominal apodemes of $2^{\text {nd }}$ tergite wide, with rounded or somewhat angular tips, separated by wide round notch (Fig. 119). Sternal apodemes narrow triangular, directed upwards, separated by rectangular notch (Fig. 120). Penis with strongly bent narrow stem in side view (Fig. 121). Males from Sakhalin (Figs 119-121) and the mainland (Figs 122-127) are similar in the shape of apodemes and penis.

HOST PLANTS. In European Russia feeds on Rubus idaeus L., $R$. caesius L., and $R$. nessensis W. Hall., in Southern Kazakhstan was found on $R$. caesius. On Sakhalin was collected from $R$. sachalinensis Lévl., which is closely related to $R$. idaeus and sometimes is considered as its subspecies (Yakubov et al., 1996).

MALE CALLING SIGNAL. Calling signal lasts from ca. 5-7 up to 30-40 s and consists of short complex components, which we somewhat conventionally refer to as syllables (Figs 160-162). Normally, syllable repetition period averages $0.9-$ $1.2 \mathrm{~s}$, occasionally it increases up to $1.7-2.0 \mathrm{~s}$. The end component of a syllable, a short succession of about 10 


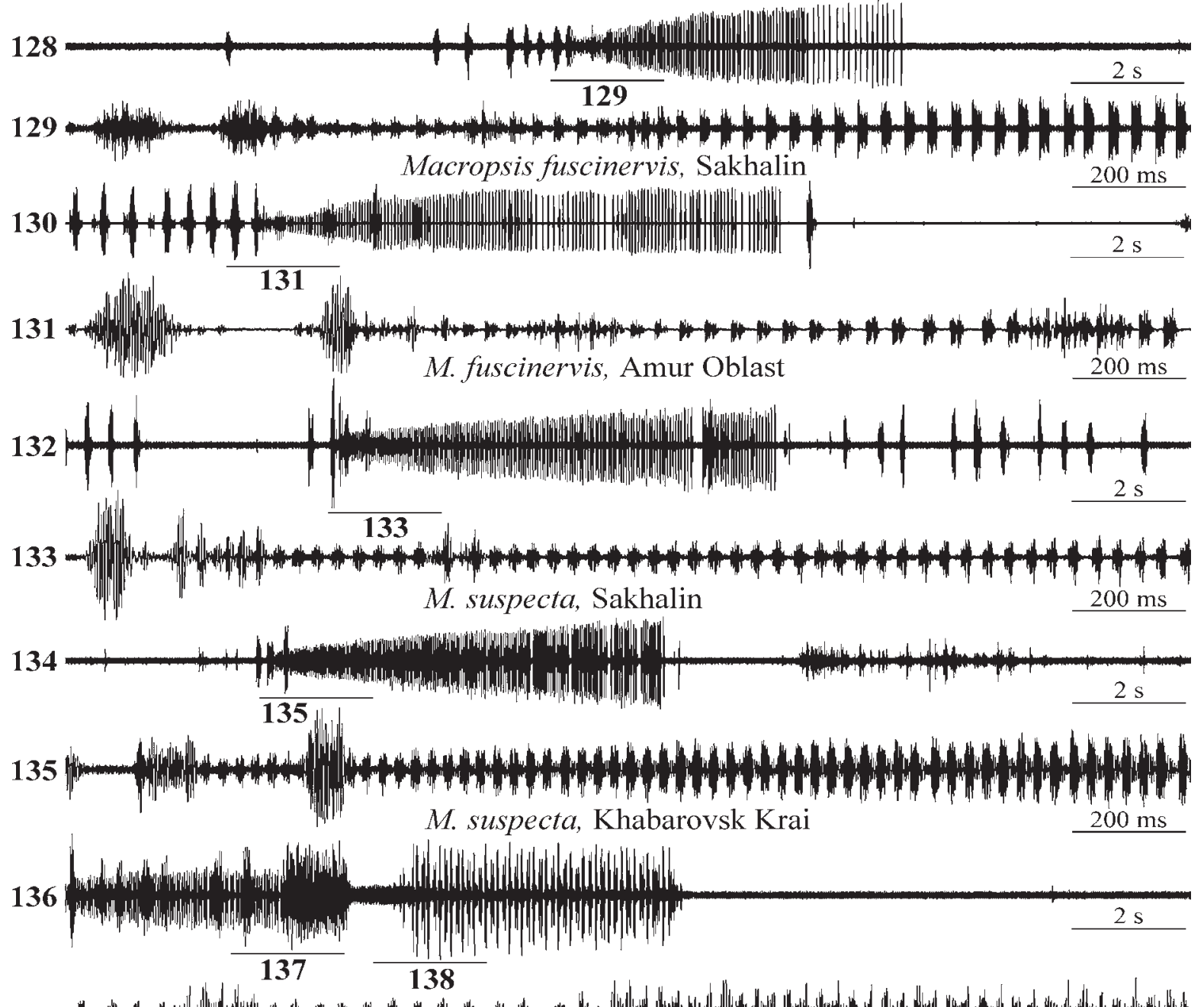

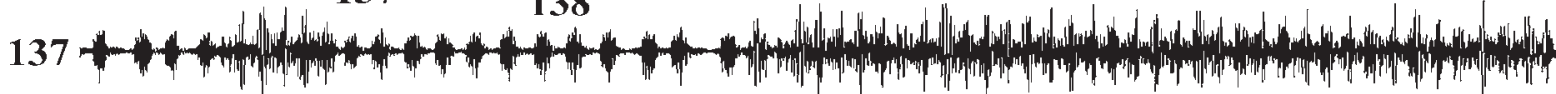

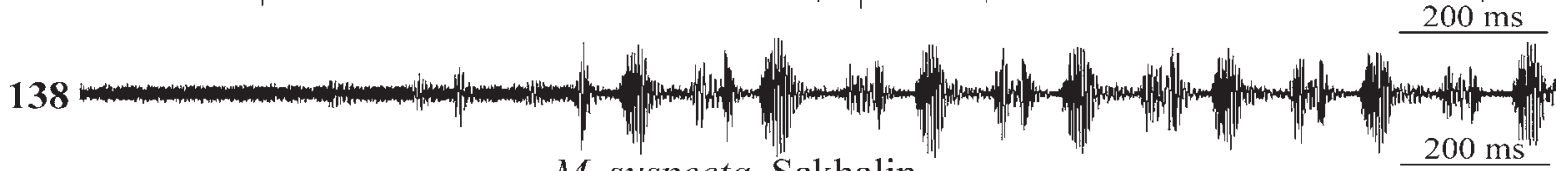

M. suspecta, Sakhalin

139 HWw

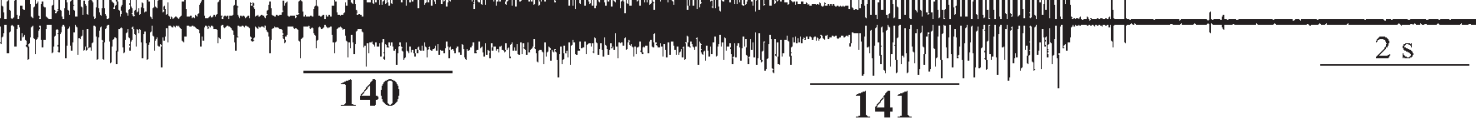

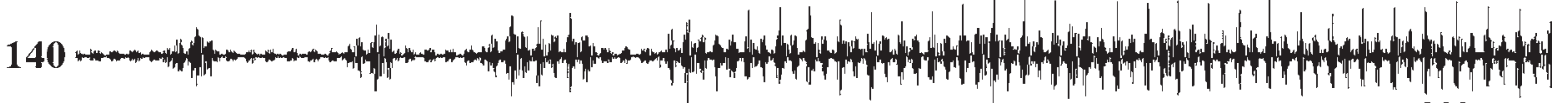

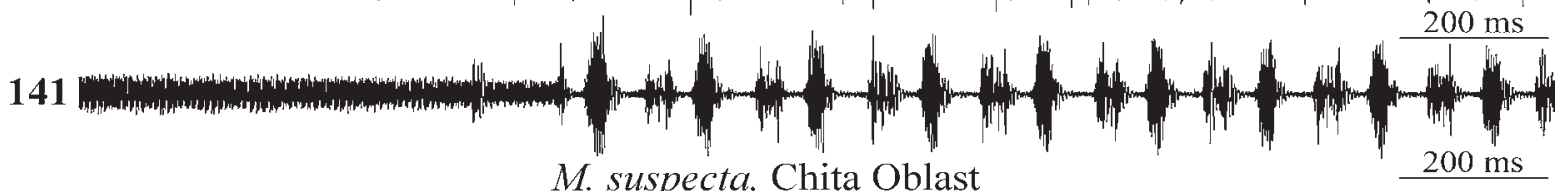

Figs 128-141. Oscillograms of male calling signals: 128-131 - Macropsis fuscinervis; 132-141 - M. suspecta; 128-135 - simple signal; 136-141 - complex signal; 128-129, 132-133, and 136-138 - males from Sakhalin; 130-131, 134-135, and 139-141 - males from the mainland. Faster oscillograms of the parts of signals indicated as "129", "131", "133", "135", "137-138", and "140-141" are given under the same numbers.

Рис. 128-141. Осциллограммы призывных сигналов: 128-131 - Macropsis fuscinervis; 132-141 - M. suspecta; 128-135 - простой сигнал; 136-141 - сложный сигнал; 128-129, 132-133 и 136-138 - самцы с Сахалина; 130-131, 134-135 и 139-141 - самцы с материка. Фрагменты сигналов, обозначенные цифрами “129”, “131”, “133”, “135”, “137-138” и “140-141”, представлены на осциллограммах под такими же номерами. 


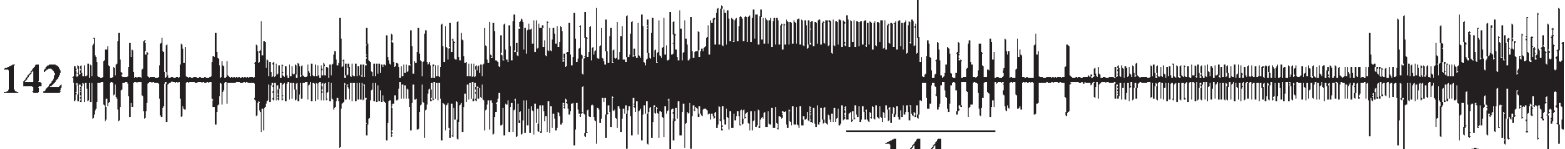

\section{$143 \quad 144$}

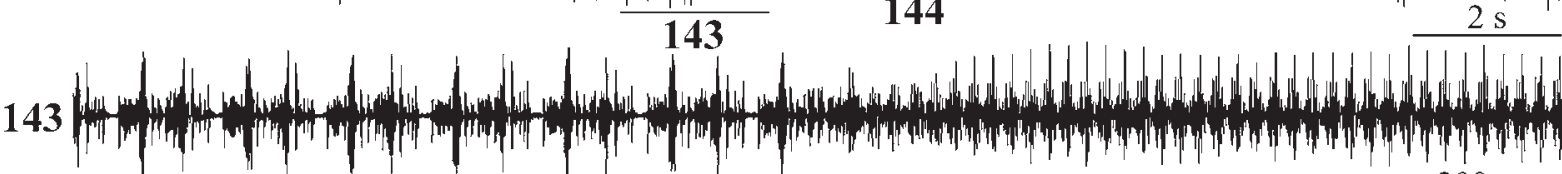
$200 \mathrm{~ms}$

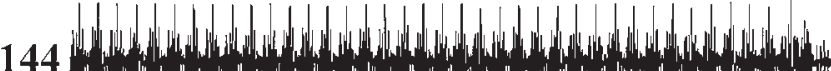

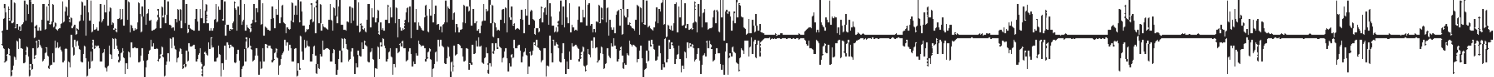
Macropsis costalis, Sakhalin

$200 \mathrm{~ms}$

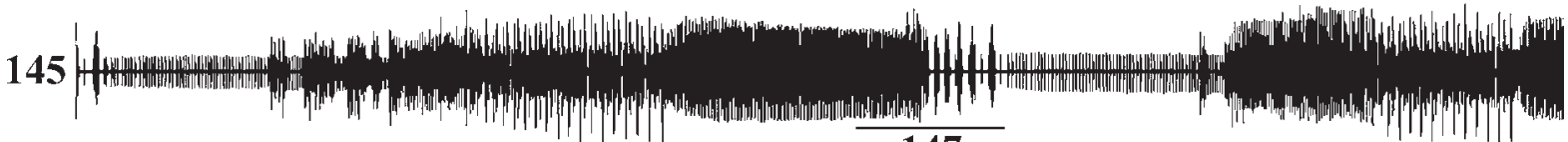
146 $2 \mathrm{~s}$

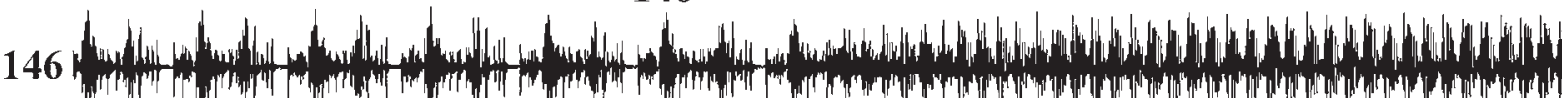
1.m.

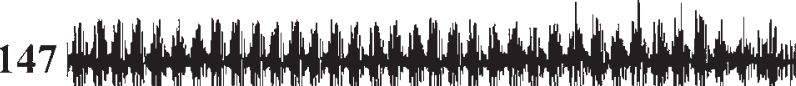

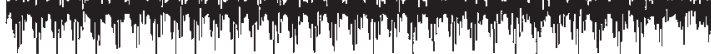

M. costalis, Primorsky Krai $200 \mathrm{~ms}$
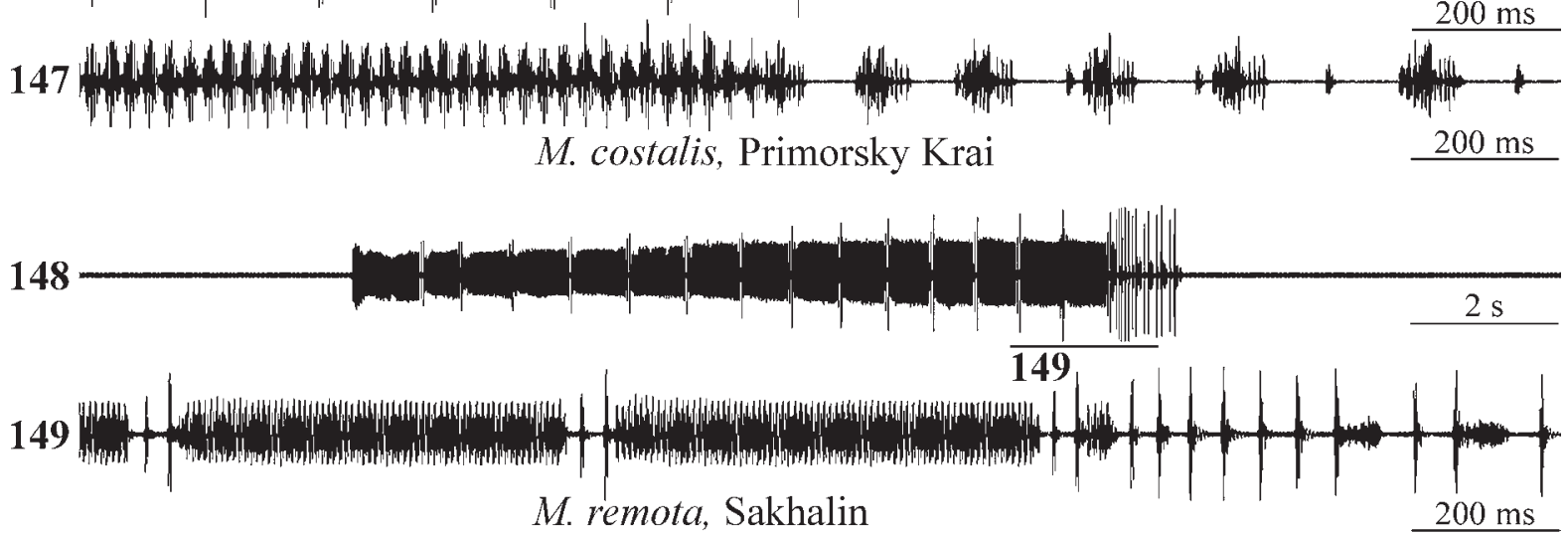

150

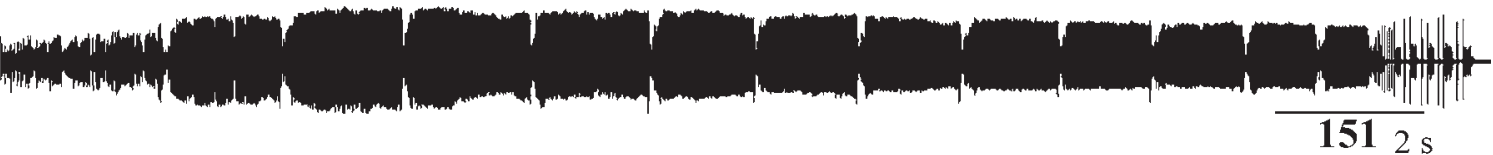

151

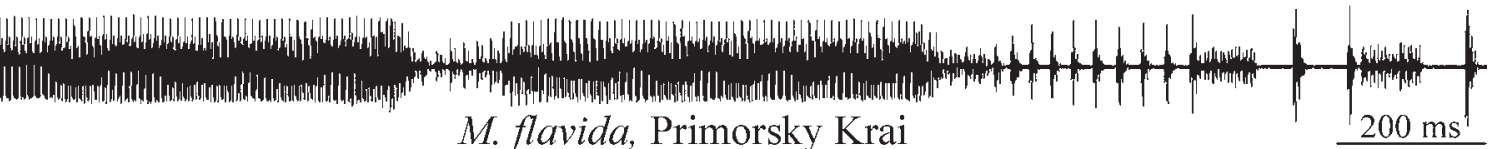

M. flavida, Primorsky Krai

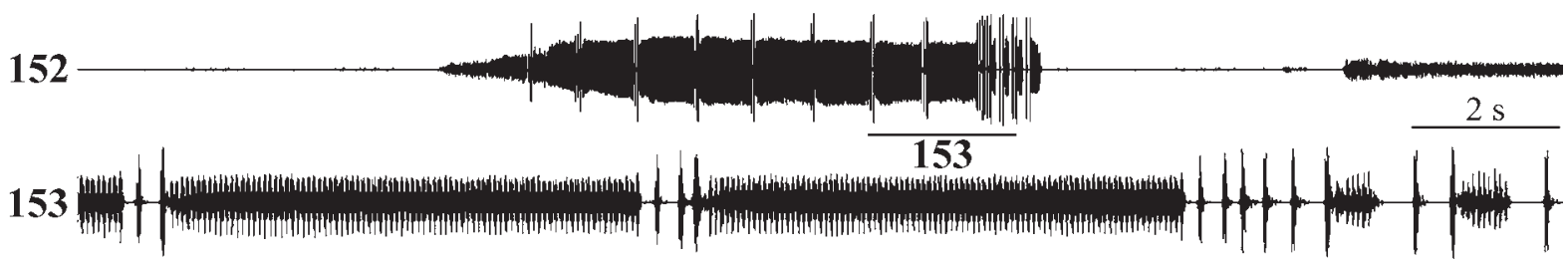

M. flavida, Amur Oblast

$200 \mathrm{~ms}$

Figs 142-153. Oscillograms of male calling signals: 142-147 — Macropsis costalis; 148-149 - M. remota; 150-153 - M. flavida; 142-144, 148-149 - males from Sakhalin; 145-147, 150-153 - males from the mainland. Faster oscillograms of the parts of signals indicated as "143-144", "146-147", "149", "151", and "153" are given under the same numbers.

Рис. 142-153. Oscillograms of male calling signals: 142-147 - Macropsis costalis; 148-149 - M. remota; 150-153 - M. flavida; 142-144, 148-149 - самцы с Сахалина; 145-147 и 150-153 - самцы с материка. Фрагменты сигналов, обозначенные цифрами “143-144”, “146-147”, “149”, “151” и “153” представлены на осциллограммах под такими же номерами. 


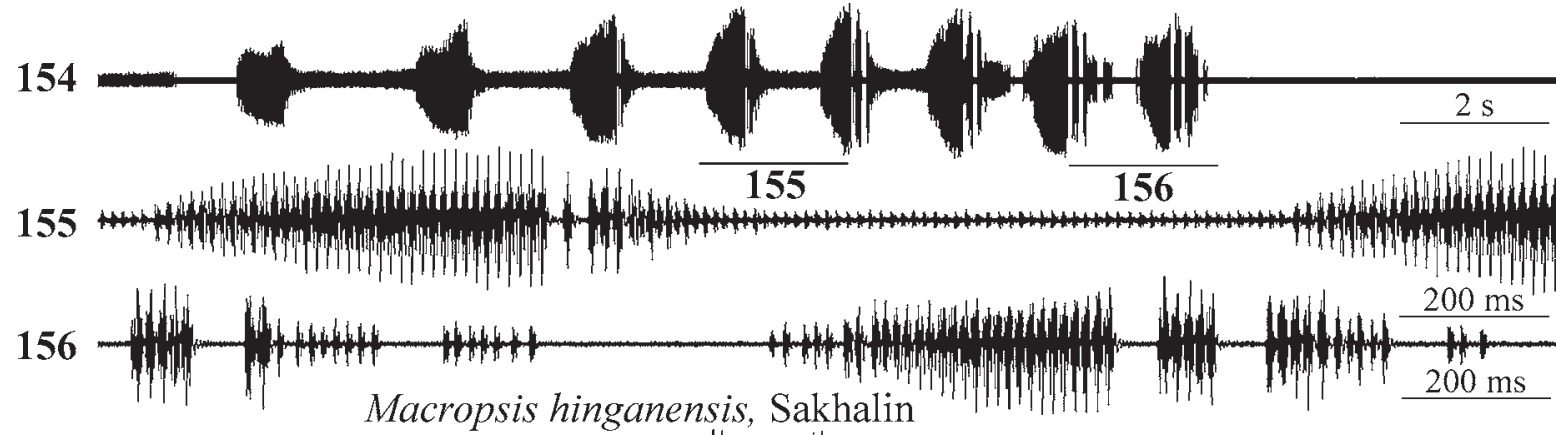

Macropsis hinganensis, Sakhalin

157

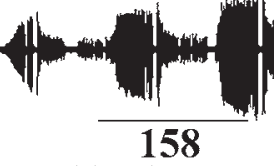

158

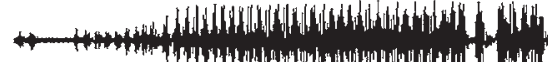

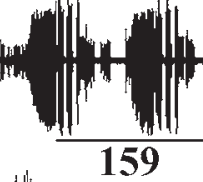

$2 \mathrm{~s}$

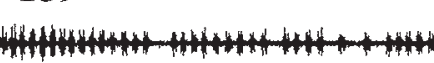

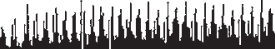

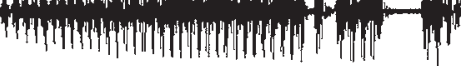

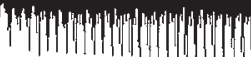

159

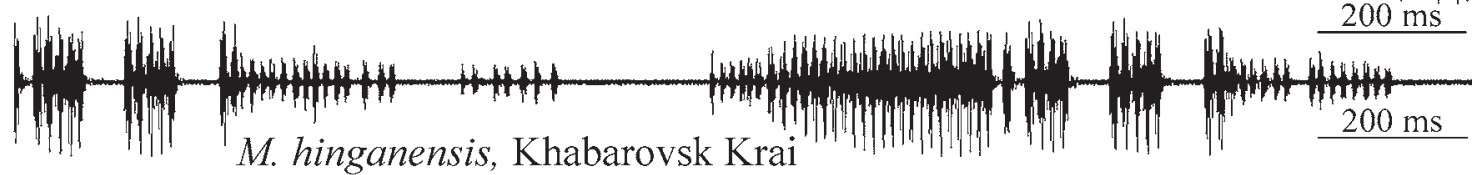

160

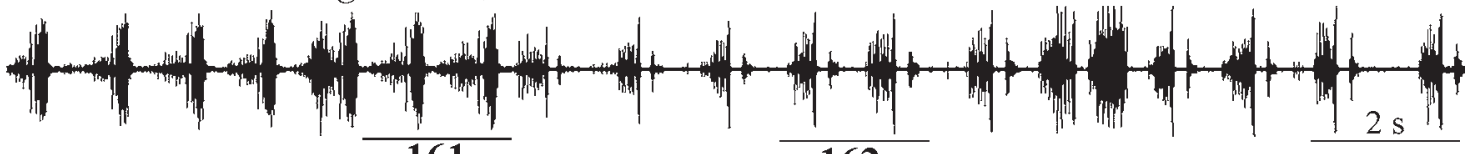

161

162

161

162

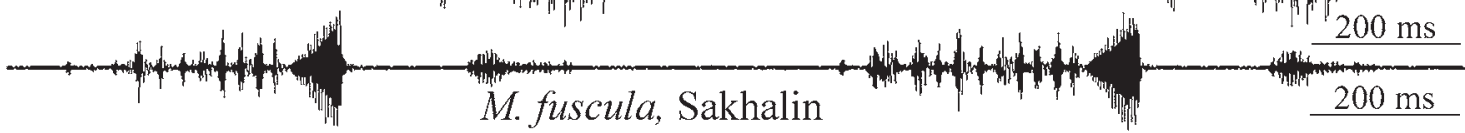

163

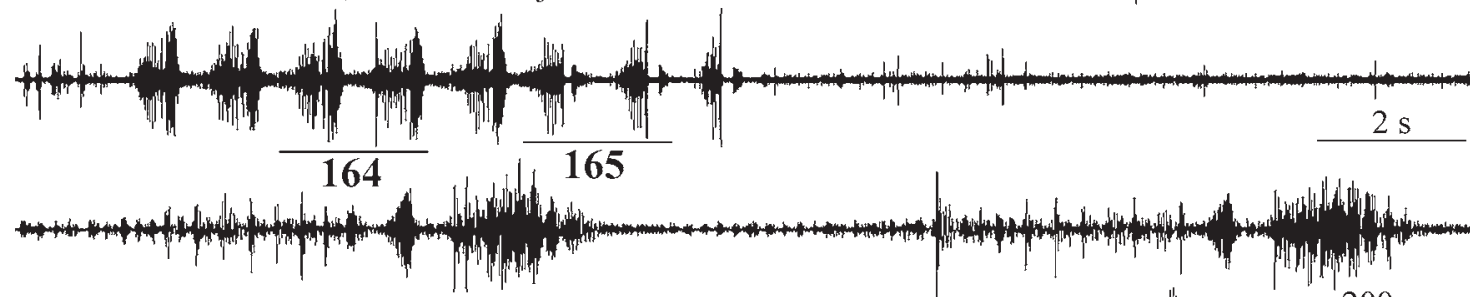

165
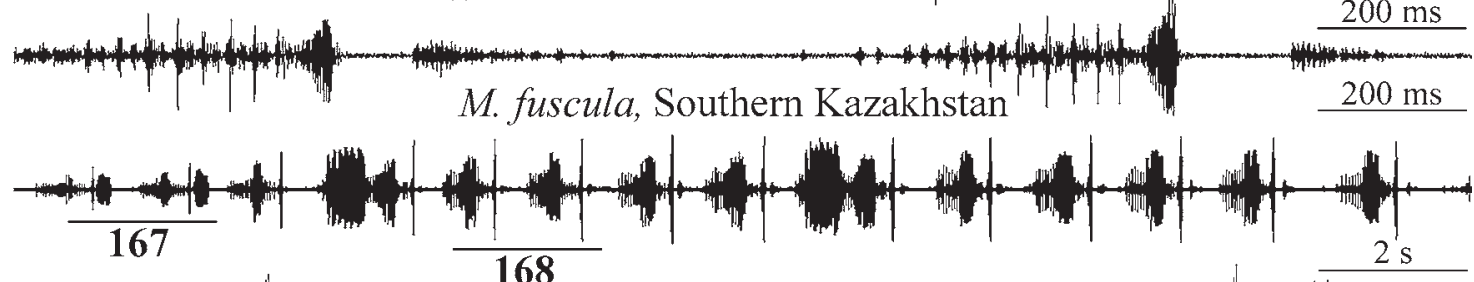

167
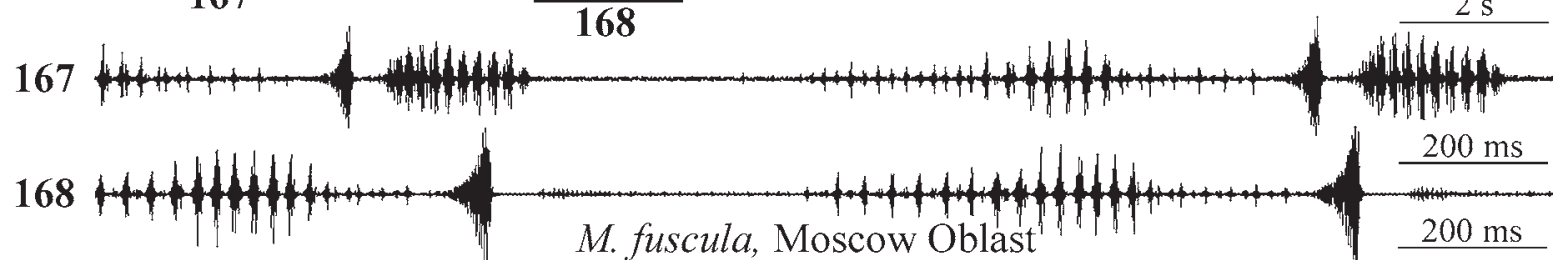

Figs 154-168. Oscillograms of male calling signals: 154-159 - Macropsis hinganensis; 160-168 - M. fuscula; 154-156 and 160162 - males from Sakhalin; 157-159 and 163-168 - males from the mainland. Faster oscillograms of the parts of signals indicated as "155156", "158-159", "161-162", "164-165", and "167-168” are given under the same numbers.

Рис. 154-168. Осциллограммы призывных сигналов: 154-159 - Macropsis hinganensis; 160-168 - M. fuscula; 154-156 и 160162 - самцы с Сахалина; 157-159 и 163-168 - самцы с материка. Фрагменты сигналов, обозначенные цифрами “155-156”, “158159”, “161-162”, “164-165” и “167-168” представлены на осциллограммах под такими же номерами. 
pulses, is often partly or completely reduced; as a rule, phrases with different pattern (Figs 161 and 162) present in the same song.

Signals of males from Sakhalin (Figs 160-162), Southern Kazakhstan (Figs 163-165), and European Russia (Figs 166168) are similar.

RANGE. Apparently, has a disjunctive range consisting of two geographically isolated parts. Known from Western Europe up to Kazakhstan and Western Siberia (Tomsk Oblast), southwards as far as Lebanon, Transcaucasia, and North Tien Shan Mts. (northern foothills of Zailiysky Alatau Mtn. Range). Was not found in Eastern Siberia, Transbaikalia, and Amur Oblast, but known from two localities in Khabarovsk Krai, from Sakhalin, and Kurile Islands (Kunashir).

REMARKS. As a rule, specimens from Western Palaearctic are distinctly darker than specimens from the Far East, whereas specimens from the mainland and insular parts of the Far East are similar. On Sakhalin this species was found on the Far Eastern species (or subspecies) of Rubus, which is absent in Western Palaearctic.

In morphological and acoustic traits no significant differences between the East and West Palaearctic populations were found.

\section{Discussion}

In M. fuscinervis, M. suspecta, M. costalis, M. hinganensis, and M. fuscula no clear differences in the shape of abdominal apodemes and penis between the mainland and insular populations were found. M. remota differs from its nearest mainland relative, $M$. flavida by the shape of the male $2^{\text {nd }}$ abdominal apodemes, more elongate and slender penis, and larger size; thus, these two forms demonstrate distinct morphological divergence.

In two cases distinct differences in coloration between the mainland and Sakhalin populations were revealed. $M$. hinganensis on Sakhalin has more variable coloration than in population from Khabarovsk Krai. On the contrary, in $M$. remota, coloration is rather uniform, whereas in its mainland sister species, $M$. flavida it is very variable. Specimens of $M$. fuscula from Khabarovsk Krai, Kurile Islands, and Sakhalin are similar, but usually have paler coloration and less developed dark pattern, than the specimens from Europe and Kazakhstan.

None of the species studied shows differences in the signal temporal pattern between the mainland and insular populations. Even in M. flavida and M. remota calling signal patterns are identical. Similarly, all six insular forms studied dwell on the same hosts as their mainland relatives or on closely related plant species.

As a result, even an example of six species shows different evolutionary scenarios in insular populations. In $M$. fuscinervis, M. suspecta, and $M$. costalis no differences in any traits between the mainland and insular populations were revealed. In $M$. hinganensis the range of colour variability on Sakhalin is much wider, than in the mainland. In M. fuscula the boundary between two colour variation is situated not between the mainland and Sakhalin, but in Eastern Siberia, where this species is absent. Anyway, in all five species differences between the insular and mainland populations are small if any.

Situation with $M$. flavida and $M$. remota is different. $M$. remota is undoubtedly an insular derivative of a widespread East Palaearctic $M$. flavida. Calling signals of these two forms are identical, which indicates their close relationship, since the convergent emergence of signals with such a complex pattern is highly unlikely. However, they distinctly differ from each other in morphological traits and apparently, already reached the rank of good species. In addition, in $M$. remota host specialization is much narrower than in its mainland sister form. Thus, only in one of six forms insular isolation resulted in speciation.

Interestingly, that in all insular forms calling signal patterns remained unchanged compared to the mainland populations, regardless of the degree of morphological differences. This proves that in geographically isolated forms, morphological divergence can occur without divergence in specific mate recognition systems i.e. in calling signal pattern.

The number of species of Macropsis on Sakhalin is considerably less, than in adjacent parts of the mainland. This is partly due to the lack of willow species, which are hosts of $M$. notata (Prohaska, 1923) and $M$. perpetua Tishetshkin, 1996 (Salix pierotii Miq.) and of M. arvicolaria Tishetshkin, 1994 (Salix sect. Helix). S. nipponica (Franch. et Savat.) (host plant of $M$. daurica Tishetshkin, 1997) and S. brachypoda (Trautv. et Mey.) Kom. (host plant of M. multa Tishetshkin, 1997) are known only from the central part of the island from one and two localities, respectively [Nedoluzhko, 1995], and were not examined.

Some species, which are abundant in the southern part of the Russian Far East and even partially penetrate to Southern Transbaikalia were not found on their host plants on Sakhalin. Despite special searches, we did not find any species of Macropsis on oaks (Quercus sp.), elms (Ulmus laciniata (Trautv.) Mayr and U. japonica (Rehd.) Sarg.), and Spiraea sp. Also, we failed to find M. leporina Tishetshkin, 1997, M. regalis Tishetshkin, 1996, and M. murina Tishetshkin, 1998 despite the fact, that their host plant, $S$. schwerinii was fairly common in the region of our investigations.

The distance from the western coast of Sakhalin to the mainland in the region of the Nevelsky Strait averages $20-30 \mathrm{~km}$ (the minimum distance is $7.5 \mathrm{~km}$ ). This is not very much for flying insects and wind-borne willow seeds. At the same time, the climate of Sakhalin is abnormally severe for its latitudes. For example, average temperatures in June and July in the Southern Transbaikalia (Aginskoe) are 16.3 and $18.8^{\circ} \mathrm{C}$, respectively; in the Southern part of Amur Oblast (Blagoveshchensk) are 18.8 and $21.6^{\circ} \mathrm{C}$, respectively; in Nikolaevsk-on-Amur (i.e. on the latitude of North Sakhalin) are 13.4 and $17.4{ }^{\circ} \mathrm{C}$, respectively; in Vladivostok are 14.5 and $19.0^{\circ} \mathrm{C}$, respectively [Climate data of cities worldwide, 2019]. Corresponding temperatures in YuzhnoSakhalinsk average 11.2 and $15.3{ }^{\circ} \mathrm{C}$, i.e. even in the 
south of the island the weather in June and July is considerably more cool than in the steppes of Transbaikalia and at the mouth of the Amur River, not to mention the zone of broadleaf forests of the Far East. Thus, it is the cold climate that is probably the reason for the absence of some continental species on this island; the impact of geographic isolation in this case, apparently, is not so great.

Acknowledgements. I am most grateful to Oleg Rychkov (Institute of Marine Biology, Russian Academy of Sciences, Vladivostok) for the help and hospitality during my visit to the Field Station of the Institute in Sokol Town, South Sakhalin and Anastasia Antonovskaya (Department of Entomology, M.V. Lomonosov Moscow State University) for her help and support during the fieldwork on Sakhalin. I am greatly indebted to Prof. Dr. Masahiro Ohara, the Hokkaido University Museum, Sapporo for sending the photographs of type specimens of S. Matsumura. The study was supported by the Russian State program No. AAAA-A16-1160216600957 (preparation of manuscript) and Russian Foundation for Basic Research, grant No. 19-04-00073 (signal analysis, morphological studies, preparation of illustrations and photographs).

\section{References}

Anufriev G.A., Emelyanov A.F. 1988. [Suborder Cicadinea (Auchenorrhyncha)] // Opredelitel' nasekomyh Dal'nego Vostoka SSSR. Vol.2. Leningrad: Nauka Publ. P.12-495 [in Russian].

Climate data of cities worldwide. https://ru.climate-data.org (accessed 23rd February 2019).

International Code of Zoological Nomenclature. Forth Edition. Russian translation. 2000. St. Petersburg. 222 pp. [In Russian]
Matsumura S. 1911. Erster Beitrag zur Insekten-Fauna von Sachalin // J. Coll. Agriculture, Tohoku Imperial Univ., Sapporo, Japan. Vol.4. No.1. P.11-45.

Matsumura S. 1912. Die Acocephalinen und Bythoscopinen Japans // J. Coll. Agriculture, Tohoku Imperial Univ., Sapporo, Japan, Vol.4. No.7. P.279-325.

Nast J. 1972. Palaearctic Auchenorrhyncha (Homoptera). An annotated check list. Warszawa, Polish Scientific Publishers. 550 pp.

Nedoluzhko V.A. 1995. Fam. 66. Willows Salicaceae // Vascular plants of the Soviet Far East. Vol.7. P.145-212 [in Russian].

Okudera S. 2014. Taxonomic notes on some Japanese macropsine leafhoppers (Auchenorrhyncha, Cicadellidae)// Rostria. Vol.57. P.13-18 [in Japanese with English summary].

Tishechkin D.Yu. 1998. New data on systematics of leafhoppers of the genus Macropsis (Homoptera, Cicadellidae) from Eastern Russia and adjacent territories // Zoologichesky Zhurnal. Vol.77. No.4. P.417-430 [in Russian, with English summary]. English translation: Entomological Review. 1998. Vol.78. No.2. P.250-263.

Tishechkin D.Yu. 1999. Review of the species of the genus Macropsis Lewis, 1834 (Homoptera: Cicadellidae: Macropsinae) from the Russian Far East and adjacent territories of Transbaikalia // Russian Entomol. J. Vol.8. No.2. P.73-113.

Tishechkin D.Yu. 2002. On taxonomy of Macropsinae leafhoppers (Homoptera, Cicadellidae) from Eastern Palaearctic // Zoologichesky Zhurnal. Vol.81. No.11. P.1329-1337 [in Russian, with English summary]. English translation: Entomological Review. 2002. Vol.82. No.9. P.1265-1273.

Tishechkin D.Yu. 2004. New data on taxonomy and distribution of species of the genus Macropsis (Homoptera, Cicadellidae) from the Russian Far East // Zoologichesky Zhurnal. Vol.83. No.1. P.49-53 [in Russian with English summary]. English translation: Entomological Review. 2004. Vol.84. No.1. P.54-58.

Tishechkin D.Yu. 2017. Review of the genus Oncopsis Burmeister, 1838 (Homoptera: Auchenorrhyncha: Cicadellidae: Macropsinae) of Russia and adjacent countries with description of a new species from Central Asia // Zootaxa. Vol.4216. No.6. P.537558. DOI: 10.11646/zootaxa.4216.6.2

Yakubov V.V., Nedoluzhko V.A., Shantzer I.A., Tikhomirov V.N., Rumyantsev S.D. 1996. [Fam. 82. Rosaceae] // Vascular plants of the Soviet Far East. Vol.8. P.125-246 [in Russian]. 